\title{
Molecular Diversity in Puccinia triticina Isolates from Ethiopia and Germany
}

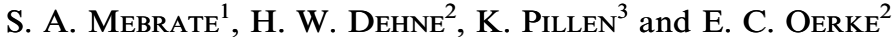 \\ Authors' addresses: ${ }^{1}$ Debre Zeit Agricultural Research Center, PO Box 32, Debre Zeit, Ethiopia; Present address: Crop \\ Protection Unit, Institute for Crop Sciences and Resource Management, University of Bonn, Nussallee 9, 53115 Bonn, \\ Germany; ${ }^{2}$ Crop Protection Unit, Institute for Crop Sciences and Resource Management, University of Bonn, Nussallee 9, \\ 53115 Bonn, Germany; ${ }^{3}$ Crop Science and Plant Breeding Unit, Institute for Crop Sciences and Resource Management, \\ University of Bonn, Katzenburgweg 5, 53115 Bonn, Germany (correspondence to E. C. Oerke. \\ E-mail: ec-oerke@uni-bonn.de)
}

Received May 4, 2006; accepted June 29, 2006

Keywords: AFLP, leaf rust, Puccinia triticina, Puccinia tritici-duri, wheat

\begin{abstract}
A total of 43 isolates of the wheat leaf rust fungus, Puccinia triticina Eriks, collected from Ethiopia and Germany were analysed for their genetic diversity using the amplified fragment length polymorphism (AFLP) technique. Out of 18 EcoRI/MseI primer combinations screened, 15 produced 219 highly polymorphic fragments. The average AFLP difference between pairs of the leaf rust isolates (26 from Ethiopia, 17 from Germany) was calculated using Dice's genetic similarity (GS) coefficient. The overall GS for the 43 isolates was $0.67 \pm 0.13$. The Ethiopian leaf rust isolates had lower average GS $(0.63 \pm 0.13)$ than the German ones $(0.76 \pm 0.10)$. A cluster analysis and a two-dimensional principal coordinate analysis (PCoA) grouped the 43 isolates into two significantly different $(\mathrm{P} \leq 0.01)$ clusters. Isolates in cluster I (35 isolates) had an average GS of $0.76 \pm 0.06$ while the isolates in cluster II (8 isolates) had an average GS of $0.55 \pm 0.12$. Isolates were also grouped into three regions of collection, central Ethiopia, south and south-east Ethiopia, and Germany. The regions were significantly different at $\mathrm{P} \leq 0.01$ indicating regional variation in terms of molecular diversity of the leaf rust isolates studied. Each isolate, however, had a unique AFLP fingerprint. The results indicated that the leaf rust population in central Ethiopia is genetically distinct and this might be related to the predominant cultivation of durum wheat cultivars in this area.
\end{abstract}

\section{Introduction}

The leaf (brown) rust fungus Puccinia triticina occurs almost everywhere where wheat is grown and is considered to be one of the most important pathogens in wheat production worldwide (Dehne and Oerke, 1998). Leaf rust causes significant yield losses every year; the disease can reduce yield by $1 \%$ for every $1 \%$ increase in the infection level (Khan et al., 1997). Although effective fungicides are available, the use of host resistance is the most economical and environment-friendly method to control the disease. Especially in developing countries where fungicides are not available or their use in low input systems is economically not justified, successful crop production depends on the use of disease-resistant cultivars. Effective breeding for disease resistance requires extensive information on the incidence and virulence of endemic pathogens; which is of high importance for rust fungi as they are able to rapidly evolve new virulent races. Knowledge on the diversity of the leaf rust fungus in Ethiopia is limited; however, information on the diversity of P. triticina isolates regularly occurring in Germany is also rare; few reports on the incidence and frequency of isolates differing in virulence genes have been published for Germany (Von Kröcher et al., 1992) and Western Europe (Park and Felsenstein, 1998; Park et al., 2000, 2001) respectively.

To study the molecular diversity of Ethiopian and German P. triticina isolates, amplified fragment length polymorphism (AFLP) analysis was chosen because AFLPs (i) generate more information per analysis than other molecular techniques, (ii) require no prior knowledge about the genetic make-up of the organism under study, (iii) are highly reproducible, and (iv) allow discrimination among closely related individuals within a species (Vos et al., 1995; Majer et al., 1996; Mueller and Wolfenbarger, 1999). AFLP markers have been successfully used in mycology and plant pathology for the differentiation of species within genera (Keiper et al., 2003; Menzies et al., 2003; Schmidt et al., 2004; Leisova et al., 2005b) as well as of isolates within species from straminopiles, ascomycetes and basidiomycetes (Schnieder et al., 2001; Rau et al., 
2002, 2005; Abd-Elsalam et al., 2003; Radisek et al., 2003; Singru et al., 2003; Martinez et al., 2004; Leisova et al., 2005a,b; Kauserud et al., 2006). Molecular techniques such as AFLP produce neutral markers in contrast to resistance-specific virulence, which is subject to strong host selection (Kolmer, 1993; Brown, 1996) and environmental conditions. Such drawbacks limit the value of virulence markers as tools for population genetics studies (Leung et al., 1993; McDonald and McDermott, 1993). Hence, only AFLP markers were used for this study with the objective of investigating the genetic variability of leaf rust isolates collected from Germany and Ethiopia.

Our general hypothesis was that genetic similarity within populations of the two countries would be considerably higher than between populations. This hypothesis might have been nullified by the existence of isolates of $P$. triticina specifically adapted to durum wheat in Central Ethiopia. Viennot-Bourgin (1941) and Ezzahiri et al. (1992) reported leaf rust pathogen genotypes specifically adapted to durum wheat [Triticum turgidum var. durum (Desf.) Husn.] in the Mediterranean region and such specificity was used to classify those pathogen genotypes into a different species, P. tritici-duri V.-Bourgin. As the importance of this pathogen is limited to the Mediterranean region, P. triticina has been widely accepted as the leaf rust fungal pathogen of cultivated wheat. Our objective was, however, to study the general molecular diversity of P. triticina isolates collected from Ethiopia and Germany. Our results, showing the genetic variability of isolates in central Ethiopia where durum wheat is predominantly cultivated, could be used as baseline information for further studies related to pathogen classification.

\section{Materials and Methods}

\section{Sources of pathogen isolates}

Ethiopian isolates of leaf rust (Puccinia triticina Eriks.) were collected from farmers' wheat (Triticum spp.) fields in the main cropping season (summer) of 2003. The collection was made in $10 \mathrm{~km}$ intervals along the roadsides. The German P. triticina isolates were kindly provided by $\mathrm{Dr}$ Kerstin Flath, Federal Biological Research Center for Agriculture and Forestry (BBA), Kleinmachnow, Germany (Table 1).

\section{Production of monopustule isolates}

Bulk collections of each sample were sparsely inoculated on detached leaf segments placed on $5 \%$ water agar in Petri dishes. The inoculated leaf segments were incubated in a chamber adjusted to $20^{\circ} \mathrm{C}$ with continuous white light. A single pustule was isolated with a moistened cotton swab and inoculated on leaf segments for multiplication. The spores harvested from the leaf segments were used to inoculate 7- to 9-dayold seedlings of the susceptible cv. Monopol, with no known leaf rust resistance gene described, for further spore production. For each isolate, six to eight pots $(7 \times 7 \times 8 \mathrm{~cm})$ thickly sown with the susceptible culti- var were used for inoculation. The inoculated plants were kept in a moist chamber for $24 \mathrm{~h}$ under a dark system at ambient temperature. Then each pot was covered with a cellophane bag $(145 \times 235 \mathrm{~mm})$ and tied with a rubber band at the base of the pot to prevent cross-contamination. While preventing contaminants, the cellophane bag allows air exchange for use by the plants inside. The inoculated seedlings were transferred to a growth chamber with $16 \mathrm{~h} / 8 \mathrm{~h}$ light/ dark system and a temperature of $20-22^{\circ} \mathrm{C}$. Spores of each isolate were harvested from infected plants 10-12 days after inoculation by tapping over aluminium foil. A total of 43 monopustule isolates were developed from bulk samples collected from the two countries.

\section{Spore germination}

Germination of spores (100 $\mathrm{mg}$ from each isolate) of the $P$. triticina isolates was basically carried out as described by Kolmer et al. (1995) except that spores were left to germinate for $12 \mathrm{~h}$ instead of $6 \mathrm{~h}$.

\section{DNA extraction}

The matt of germinated spores of individual isolates were ground with sterilized sand and liquid nitrogen. The DNeasy Plant Mini Kit (Qiagen, Hilden, Germany) was used to extract DNA from the germinated matt of spores and germ tubes of each isolate. The working concentration of DNA was adjusted to $50 \mathrm{ng} / \mu \mathrm{l}$.

\section{Determination of AFLP genotypes}

Digestion of template DNA with Tru9I and EcoRI enzymes The template DNA of each isolate $(5 \mu \mathrm{l}$ of $50 \mathrm{ng} / \mu \mathrm{l}$ concentration) was digested with $0.25 \mu \mathrm{l}$ $\operatorname{Tr} u 9 \mathrm{I}(10 \mathrm{U} / \mu \mathrm{l})$ (Promega, Mannheim, Germany), $2 \mu \mathrm{l}$ of $10 \mathrm{X}$ buffer $\mathrm{F}$ in $12.75 \mu \mathrm{l}$ of $\mathrm{dd}_{2} 0$ for $2 \mathrm{~h}$ at $65^{\circ} \mathrm{C}$. The Tru9I products $(20 \mu \mathrm{l})$ were again digested with $0.25 \mu \mathrm{l}$ of $12 \mathrm{U} / \mu \mathrm{l} E c o \mathrm{RI}$ (Promega) and $2.5 \mu \mathrm{l}$ of $10 \mathrm{X}$ buffer $\mathrm{H}_{\text {mod. }}$ in a total reaction volume of $25 \mu \mathrm{l}$.

Adaptor ligation Ligation of adaptors was carried out for $2 \mathrm{~h}$ at $20^{\circ} \mathrm{C}$ using $12.5 \mu \mathrm{l}$ of the digested product, $0.125 \mu \mathrm{l}$ of each adaptor: $1 \mathrm{~mm}$ AD-Eco $\mathrm{F}$ [5'-CTC GTA GAC TGC GTA CC-3'], 1 mM AD-Eco R [5'AAT TGG TAC GCA GTC TAC- $3^{\prime}$ ], 1 mm AD-MseI F [5'-GAC GAT GAG TCC TGA G-3'] and $1 \mathrm{~mm}$ AD-MseI R [5'-TAC TCA GGA CTC AT-3'], and $0.084 \mu \mathrm{l}$ of $3 \mathrm{U} / \mu \mathrm{l}$ T4 DNA-ligase (Promega) with $2.5 \mu \mathrm{l} 10 \mathrm{X}$ ligase buffer and $9.416 \mu \mathrm{l} \mathrm{ddH}_{2} 0$. The total reaction volume was $25 \mu \mathrm{l}$. The ligation product was diluted to $1: 20$ for use in the preamplification step.

Preamplification The preamplification polymerase chain reaction (PCR) was carried out using $5 \mu \mathrm{l}$ of $1: 20$ diluted ligation product as template DNA, and $2.5 \mu \mathrm{l} 10 \mathrm{X}$ PCR buffer, $2.5 \mu \mathrm{l} \mathrm{MgCl}_{2}(25 \mathrm{~mm}), 2.5 \mu \mathrm{l}$ dNTP-mix $(2 \mathrm{mM}), 1 \mu \mathrm{l}$ of primer E01 $(10 \mu \mathrm{M})\left(5^{\prime}-\right.$ GAC TGC GTA CCA ATT CA-3'), $1 \mu$ primer M02 $(10 \mu \mathrm{M})\left(5^{\prime}\right.$-GAT GAG TCC TGA GTA AC-3'), $0.1 \mu \mathrm{l}$ of $1 \mathrm{U} \mathrm{Taq}$-polymerase (Promega) with $10.4 \mu \mathrm{l} \mathrm{ddH}_{2} \mathrm{O}$ 
Table 1

Wheat leaf rust isolates, origin, host cultivar, and year of collection

\begin{tabular}{|c|c|c|c|}
\hline Isolate & Origin & Host cultivar & Year of collection \\
\hline Ak9-3 & Akaki, CE & Pavon-76, BW & 2003 \\
\hline Alemgena & Alemgena, CE & Gerardo, DW & 2003 \\
\hline Bekoji & Bekoji, SSE & Galama, BW & 2003 \\
\hline $\mathrm{CD}$ & Chefe Donsaia, CE & Israel, BW & 2003 \\
\hline Dodolla & Dodolla, SSE & $\mathrm{N} / \mathrm{a}, \mathrm{BW}$ & 2003 \\
\hline DZ7-21 & Debre Zeit, CE & Arendeto, DW & 2003 \\
\hline DZ7-23 & Debre Zeit, CE & $\mathrm{N} / \mathrm{a}, \mathrm{DW}$ & 2003 \\
\hline DZ7-24 & Denkaka-Debre Zeit, CE & N/a, BW & 2003 \\
\hline E-4 & Goffer Estate Farm, SSE & N/a, BW & 2003 \\
\hline E-8 & Sama Senbet, CE & Pavon-76, BW & 2003 \\
\hline E-16 & Tefki, CE & Kubsa, BW & 2003 \\
\hline E-19 & Keta-Tulubollo, CE & N/a, BW & 2003 \\
\hline E-22-2 & Wolliso-Goro, CE & Kubsa, BW & 2003 \\
\hline E-23 & Wolliso, CE & Israel, BW & 2003 \\
\hline E-30 & Shenshicho, SSE & $\mathrm{N} / \mathrm{a}, \mathrm{BW}$ & 2003 \\
\hline E-33 & Durame, SSE & Dashen, BW & 2003 \\
\hline E-35 & Butajira, SSE & $\mathrm{N} / \mathrm{a}, \mathrm{BW}$ & 2003 \\
\hline E-43 & Womber Godeti, SSE & Gerardo, DW & 2003 \\
\hline E-52 & Gogecha-Akaki, CE & Pavon-76, BW & 2003 \\
\hline KK & Kersana Kondaltiti, SSE & Pavon-76, BW & 2003 \\
\hline Minjarl & Minjar, CE & Pavon-76, BW & 2003 \\
\hline Minjar2 & Minjar-Arerti, CE & Pavon-76, BW & 2003 \\
\hline PPRC2-1 & Lemo, SSE & Katar, BW & 2003 \\
\hline PPRC2-3 & Lemo, SSE & Katar, BW & 2003 \\
\hline PPRC3-1 & Adaali, SSE & Abola, BW & 2003 \\
\hline PPRC3-3 & Adaali, SSE & Abola, BW & 2003 \\
\hline Bonn1 & Bonn, Germany & Dekan, BW & 2004 \\
\hline Bonn2 & Bonn, Germany & Munk, BW & 2004 \\
\hline K-B1 & Lower Saxony, Germany & Denver, BW & 2003 \\
\hline K-B2 & Lower Saxony, Germany & Dekan, BW & 2003 \\
\hline Mon1-p10 & Mainz, Germany & Monopol, BW & 2003 \\
\hline $167-176$ & Germany & $\mathrm{N} / \mathrm{a}$ & Before 1990 \\
\hline $77 \mathrm{~W} \times \mathrm{R}$ & Germany & $\mathrm{N} / \mathrm{a}$ & Before 1990 \\
\hline WBR1 & Germany & $\mathrm{N} / \mathrm{a}$ & Before 1990 \\
\hline WBR2 & Germany & $\mathrm{N} / \mathrm{a}$ & Before 1990 \\
\hline WBR3 & Aschersleben, Germany & Borenos, BW & 2001 \\
\hline WBR4 & Bonn, Germany & Dekan, BW & 2003 \\
\hline WBR5 & Bonn, Germany & Dekan, BW & 2003 \\
\hline WBR6 & Bonn, Germany & Drifter, BW & 2003 \\
\hline WBR7 & Bonn, Germany & Drifter, BW & 2003 \\
\hline WBR10 & Mainz, Germany & Punch, BW & 2003 \\
\hline WBR12 & Mainz, Germany & Dekan, BW & 2003 \\
\hline WBR14 & Mainz, Germany & Monopol, BW & \\
\hline
\end{tabular}

CE, central Ethiopia; SSE, south and south-east Ethiopia; BW, bread wheat Triticum aestivum L.; DW, durum wheat Triticum turgidum var durum (Desf.) Husn.; N/a, name of a specific variety not available. in a total reaction volume of $25 \mu 1$. The PCR comprised 20 cycles of $94^{\circ} \mathrm{C}$ for $30 \mathrm{~s}, 56^{\circ} \mathrm{C}$ for $60 \mathrm{~s}$ and $72^{\circ} \mathrm{C}$ for $60 \mathrm{~s}$. The preamplification product was then diluted $1: 300$ for use in the selective amplification.

Selective amplification In this final step, $5 \mu \mathrm{l}$ of the diluted preamplification product, $1.5 \mu \mathrm{l} 10 \mathrm{X}$ PCR buffer, $1.5 \mu \mathrm{l} \mathrm{MgCl}_{2}$ (25 mM), $1.5 \mu \mathrm{l}$ dNTP-mix (2 mM), $0.6 \mu \mathrm{l} E c o$ RI primer with two selective nucleotides $(1 \mu \mathrm{M}), 0.6 \mu \mathrm{l} \mathrm{MseI}$ primer with three selective nucleotides $(10 \mu \mathrm{M})$ and $0.1 \mu \mathrm{l}$ of $1 \mathrm{U}$ Taq polymerase (Promega) were used with $4.2 \mu \mathrm{l} \mathrm{ddH}_{2} 0$ for the selective amplification. The total reaction volume was $15 \mu \mathrm{l}$. The EcoRI primers were labelled with near-infrared IRD700 fluorescent dye for later detection on a Li-COR 4200 System (Li-COR Biosciences, Bad Homburg, Germany). The 'touch-down' PCR (decreasing the annealing temperature by $0.7^{\circ} \mathrm{C}$ per cycle) comprising 13 cycles of $94^{\circ} \mathrm{C}$ for $30 \mathrm{~s}$ to denature the sample, $65-56^{\circ} \mathrm{C}$ for $60 \mathrm{~s}$ for annealing, $72^{\circ} \mathrm{C}$ for $60 \mathrm{~s}$ for extension, and 23 cycles of $94^{\circ} \mathrm{C}$ for $30 \mathrm{~s}$ for denaturation, $65^{\circ} \mathrm{C}$ for $60 \mathrm{~s}$ for annealing and $72^{\circ} \mathrm{C}$ for $60 \mathrm{~s}$ for extension was used. A total of $18 \mathrm{EcoRI} / \mathrm{MseI}$ primer combinations were screened.

Electrophoresis of AFLPS The PCR-amplified products were denatured at $95^{\circ} \mathrm{C}$ for $3 \mathrm{~min}$ before loading onto a $6 \%$ polyacrylamide gel. The polyacrylamide gel was prepared from $24 \mathrm{ml}$ reagent (SequaGel XR; Biozym Diagnostik, Hessisch-Oldendorf, Germany), $6 \mathrm{ml}$ buffer (SequaGel Complete; Biozym Diagnostik), and $240 \mu 110 \%$ ammonium peroxide sulphate. The gel was poured between two $41 \mathrm{~cm}$ glass plates $(0.2 \mathrm{~mm}$ spacers fixed between the plates in opposite sides) and $0.4 \mu \mathrm{l}$ per sample was loaded onto the gel. A standard size ladder, $0.3 \mu \mathrm{l}$ of $700 \mathrm{bp}$ (Li-COR Biosciences) was loaded twice, one in the beginning and another in the centre of the gel as a sizer. The 43 isolates were divided into two sets and each set was run on a separate 
gel. In every case, an internal control isolate (E-52) was loaded twice in double adjacent lanes each, one in the beginning and the other in the middle of the gel. Each isolate was amplified twice and loaded in double adjacent lanes to ensure the repeatability of the data. AFLP fragments were separated electrophoretically for $3 \mathrm{~h}$ in the Li-COR 4200 system (Li-COR Biosciences). Subsequently, the bands were scored manually as present (1) or absent (0).

\section{Data analysis}

Only unambiguous polymorphic fragments giving the same results from two independent PCRs were considered for scoring in each primer combination and the statistical software, NTSYS-pc ver. 2.0 (Exeter Software, East Setauket, NY, USA), was used for analysis of the AFLP data.

\section{Genetic similarity}

The average AFLP difference between pairs of the 43 leaf rust isolates was calculated using Dice's genetic similarity (GS) coefficient (Nei and Li, 1979). The GS between two isolates $i$ and $j$ is equivalent to the formula, GS $[\mathrm{DICE}]=2 a /(2 a+b+c)$, where $a$ represents bands present in both isolates $i$ and $j, b$ represents bands present in isolate $i$ but absent in $j$, and $c$ represents bands present in isolate $j$ but absent in isolate $i$.

\section{Grouping of pathogen isolates based on region of collection}

To have more insight into the molecular diversity of the pathogen isolates, three groups were differentiated based on the region of collection. The first region consisted of 17 isolates of $P$. triticina collected from Germany: 167-176, WBR14, Bonn1, Bonn2, WBR1, K-B1, Mon1-p10, 77WxR, WBR7, WBR5, WBR4, WBR10, WBR12, K-B2, WBR2, WBR3 and WBR6. Bread wheat is the major type of wheat grown in Germany. South and south-eastern Ethiopia formed the second region with 12 isolates: E-30, E-33, E-35, E-43, KK, PPRC2-1, PPRC2-3, PPRC3-1, PPRC3-3, Bekoji, Dodolla and E-4. This region is known for its bread wheat production. According to Ensermu et al. (1998), about $75 \%$ of Ethiopia's bread wheat area is located in Arsi (south-east Ethiopia). The third region of collection, central Ethiopia, consisted of 14 isolates: Ak9-3, Alemgena, CD, DZ7-21, DZ7-23, DZ7-24, E-16, E-19, E-22-2, E-23, E-52, E-8, Minjar1 and Minjar2. This region is mainly known for its durum wheat production but bread wheat is also becoming an increasingly important crop (Badebo, 2002) due to its higher yield and wider adaptability (Geleta and Tanner, 1995).

\section{Cluster analysis}

Based on the GS values, a cluster analysis between the isolates was performed by the unweighted pair group arithmetic mean average (UPGMA) method and a dendrogram was developed for clustering isolates.

\section{Principal coordinate analysis}

A two-dimensional principal coordinate analysis (PCoA) was also developed by the NTSYS software to plot the genetic similarity of the isolates, as outlined by Pillen et al. (2000).

\section{Allele frequency}

To measure how often or common an allele was found in the respective populations, allele frequency was calculated as the percentage of isolates that the allele occupies within the population.

\section{Results}

Of the $18 E c o R I / M s e I$ primer combinations screened, 15 were found to produce 219 reproducible and highly polymorphic fragments that were easy to score (Table 2). Each primer combination produced 10-19 polymorphic AFLP fragments. The internal control, E-52, present in the first and second set of isolates was analysed as two separate isolates (E-52 and E-52a). The duplicates were found to be identical based on AFLP fingerprints with a GS value of 1.00 (or $100 \%$ genetic similarity) indicating the reliability of data. Overall GS for all the isolates tested was $0.67 \pm 0.13$. The Ethiopian leaf rust isolates had an average GS of $0.63 \pm 0.13$ which was lower than the average GS of the German isolates (GS $0.76 \pm 0.10$ ). The 43 wheat leaf rust isolates were clustered into two major groups (Fig. 1).

Grouping of pathogen isolates based on the region of collection Within-region comparison Each region of collection was highly significantly different $(\mathrm{P} \leq 0.01)$ from the other in terms of the GS of isolates in the respective regions (Table 3). Isolates from Germany had the highest average GS of $0.76 \pm 0.10$ followed by the isolates from south and south-east Ethiopia (GS $0.70 \pm 0.13)$. Isolates from central Ethiopia had the least average GS of $0.61 \pm 0.10$ of the three regions. Standard deviations within the isolates from the different regions were very similar.

Between-regions comparison The average GS between isolates collected from Germany and south and southeast Ethiopia was $0.72 \pm 0.11$, a value significantly lower than the average GS within the German isolates. The average GS between isolates collected from Germany and central Ethiopia was $0.65 \pm 0.12$, between the isolates from the two Ethiopian regions $(0.64 \pm 0.12)$.

\section{Cluster analysis}

As indicated in Table 4, the 43 isolates collected from the two countries were categorized into two significantly $(\mathrm{P} \leq 0.01)$ distinct clusters.

Cluster I The majority of isolates from both countries - 16 from Germany and 19 from Ethiopia were grouped together in this cluster. The 35 isolates 
Table 2

Selected EcoRI/MseI primer combinations and the corresponding polymorphic fragments produced among the 43 leaf rust isolates ${ }^{\mathrm{a}}$

\begin{tabular}{|c|c|c|}
\hline EcoRI primer & MseI primer & Polymorphic fragments \\
\hline 5'-GAC TGC GTA CCA ATT CAA-3' & 5'-GAT GAG TCC TGA GTA ACA A-3' & 19 \\
\hline 5'-GAC TGC GTA CCA ATT CAA-3' & 5'-GAT GAG TCC TGA GTA ACA C- $3^{\prime}$ & 14 \\
\hline 5'-GAC TGC GTA CCA ATT CAA-3' & 5'-GAT GAG TCC TGA GTA ACA G-3' & 17 \\
\hline 5'-GAC TGC GTA CCA ATT CAA-3' & 5'-GAT GAG TCC TGA GTA ACT A-3' & 12 \\
\hline 5'-GAC TGC GTA CCA ATT CAA-3' & 5'-GAT GAG TCC TGA GTA ACT C-3' & 10 \\
\hline 5'-GAC TGC GTA CCA ATT CAA-3' & 5'-GAT GAG TCC TGA GTA ACT G-3' & 19 \\
\hline 5'-GAC TGC GTA CCA ATT CAC-3' & 5'-GAT GAG TCC TGA GTA ACA G-3' & 13 \\
\hline 5'-GAC TGC GTA CCA ATT CAC-3' & 5'-GAT GAG TCC TGA GTA ACT A-3' & 14 \\
\hline 5'-GAC TGC GTA CCA ATT CAC-3' & 5'-GAT GAG TCC TGA GTA ACT C-3' & 13 \\
\hline 5'-GAC TGC GTA CCA ATT CAC-3' & 5'-GAT GAG TCC TGA GTA ACT G-3' & 10 \\
\hline 5'-GAC TGC GTA CCA ATT CAG-3' & 5'-GAT GAG TCC TGA GTA ACA A-3' & 16 \\
\hline 5'-GAC TGC GTA CCA ATT CAG-3' & 5'-GAT GAG TCC TGA GTA ACA C-3' & 19 \\
\hline 5'-GAC TGC GTA CCA ATT CAG-3' & 5'-GAT GAG TCC TGA GTA ACA G-3' & 14 \\
\hline 5'-GAC TGC GTA CCA ATT CAG-3' & 5'-GAT GAG TCC TGA GTA ACT C-3' & 14 \\
\hline 5'-GAC TGC GTA CCA ATT CAG-3' & 5'-GAT GAG TCC TGA GTA ACT G-3' & 15 \\
\hline Total & & 219 \\
\hline
\end{tabular}

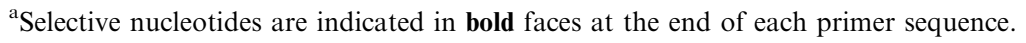

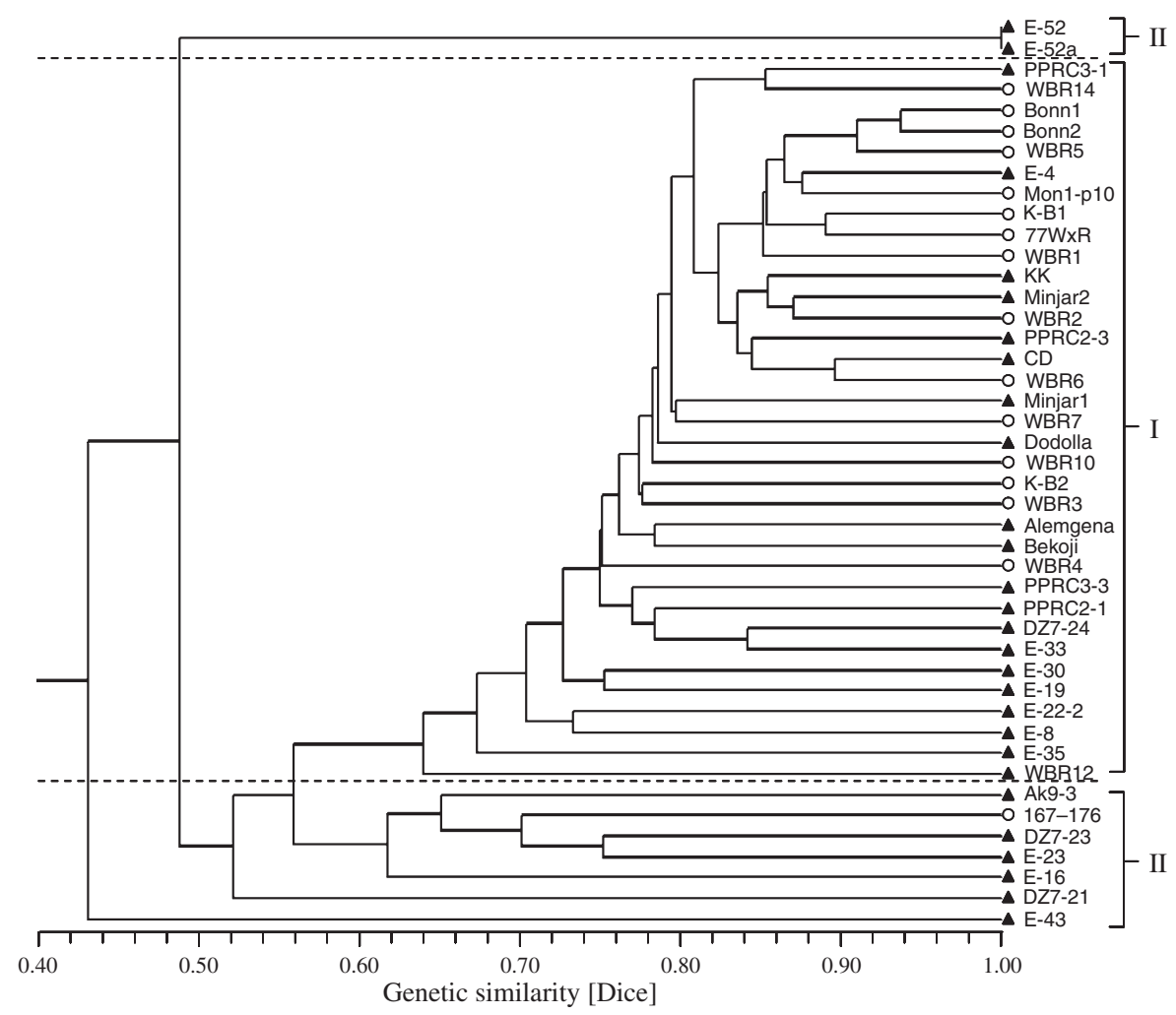

Fig. 1 Dendrogram produced using the unweighted pair-group arithmetic mean average (UPGMA) method based on GS coefficients calculated from 219 different AFLP fragments. Scale indicates Dice's GS values among the 43 isolates of Puccinia triticina collected from Ethiopia (A) and Germany (O). The dendrogram is divided into two major clusters (I and II), as indicated on the right-hand side of the figure

in this cluster had an average GS value of $0.76 \pm 0.06$. The two genetically most similar isolates were Bonn1 and Bonn2 with a GS value of 0.94. There was also high GS (0.90) between the Ethiopian isolate $\mathrm{CD}$ and the German isolate WBR6. Another high similarity (GS 0.89) was observed between the two German isolates K-B1 and $77 \mathrm{~W} \times \mathrm{R}$. In general, there was more genetic similarity within pairs of isolates in cluster I than in cluster II.
Cluster II This group contained seven isolates (without the purposely duplicated control isolate E-52a) from Ethiopia and one isolate, 167-176, from Germany. Isolates in this cluster had an average GS value of $0.55 \pm 0.12$. The two genetically closest isolates in the cluster were E-23 and DZ7-23 with a GS value of 0.75. Except E-43, an isolate collected from durum wheat grown in south and south-east Ethiopia, all Ethiopian isolates in this cluster originated from the central region. 
Table 3

Average genetic similarity values for the wheat leaf rust isolates grouped by region of collection

\begin{tabular}{lcc}
\hline Comparison & $\begin{array}{c}\text { Combinations } \\
\text { of isolates }(n)\end{array}$ & $\begin{array}{c}\text { Average genetic } \\
\text { similarity }\end{array}$ \\
\hline Within regions & & \\
$\quad$ Ger & 136 & $0.76 \pm 0.10 \mathrm{a}$ \\
SSE & 66 & $0.61 \pm 0.13 \mathrm{~b}$ \\
CE & 91 & $0.10 \mathrm{c}$ \\
Between regions & 204 & $0.65 \pm 0.11 \mathrm{a}$ \\
Ger $\times$ SSE & 238 & $0.64 \pm 0.12 \mathrm{bc}$ \\
Ger $\times$ CE & 168 &
\end{tabular}

Ger, Germany; SSE, south and south-east Ethiopia; CE, central Ethiopia.

${ }^{\mathrm{a}} \mathrm{GS}$ (mean \pm standard deviation) with different lower-case letters are significantly different at $\mathrm{P} \leq 0.01$ (Student-Newman-Keuls test).

Table 4

Average genetic similarity values of the wheat leaf rust isolates within and between clusters

\begin{tabular}{lcc}
\hline Comparison & Combinations of isolates $(n)$ Genetic similarity $^{\mathrm{a}}$ \\
\hline Cluster $1 \times$ cluster 1 & 595 & $0.76 \mathrm{a}$ \\
Cluster $2 \times$ cluster 2 & 28 & $0.55 \mathrm{~b}$ \\
Cluster $2 \times$ cluster 1 & 280 & $0.53 \mathrm{~b}$
\end{tabular}

${ }^{a}$ Mean GS with different lower-case letters are significantly different at $\mathrm{P} \leq 0.01$ (Student-Newman-Keuls test).

\section{Principal coordinate analysis}

Two-dimensional principal coordinate plots based on Dice's GS values divided the 43 isolates into two major groups (Fig. 2). These are located in sections II and IV of the PCoA plot. Section II included eight isolates, seven from Ethiopia (without considering E-52a as a separate isolate) and one from Germany. These same eight isolates were also grouped together in cluster II of the dendrogram in Fig. 1. Correspondingly, the same 35 isolates (19 from Ethiopia and 16 from Germany) in section IV were grouped together in a similar manner as shown in cluster I of the dendrogram in Fig. 1.

\begin{abstract}
Allele frequency
The overall frequency of AFLP alleles in the $P$. tritici$n a$ isolates was $58.4 \pm 10.0$ (median 60.3) and varied from 30.6 (isolate E-43) to 79.0 (isolate CD). With very similar frequencies for most of the Ethiopian and German isolates, the allele frequency of isolates E-43 and DZ7-21, both isolated from durum wheat, was significantly lower $(30.6 \%$ and $37.9 \%$ respectively). All alleles detected in the AFLP analysis were represented in the Ethiopian wheat leaf rust population studied, whereas eight alleles were missing in the German isolates of $P$. triticina (data not shown). Of the total 219 alleles, 20 were detected in all German isolates; none of the alleles were shared by all Ethiopian isolates tested.
\end{abstract}

The allele E-AC/M-CTG-8 was missing in both German and south and south-east Ethiopian populations
(Table 5). However, this allele was shared by three isolates (allele frequency 21\%) in the central Ethiopian population. Another missing allele in the German population, E-AC/M-CTC-6, was detected only in isolate E-43 from durum wheat in the south and south-east Ethiopian population while it was detected in three isolates of the central Ethiopian population (frequency $21 \%$ ). Conversely, allele E-AG/M-CAG-6 was detected in all isolates of both, the south and south-east Ethiopian and the German collection. This allele, however, was detected only in eight isolates from central Ethiopia (frequency 57\%). Another allele with high frequency in both German $(100 \%)$ and south and south-east Ethiopian (92\%) populations was E-AG/ $\mathrm{M}-\mathrm{CAC}-17$. This allele was present only in eight isolates of the central Ethiopian (frequency 57\%) population. Allele E-AG/M-CAG-9 was also detected in all German isolates and in 10 isolates from south and south-east Ethiopia (frequency $83 \%$ ). This allele was shared only by seven isolates in the central Ethiopian population (frequency $50 \%$ ).

\section{Discussion}

All isolates of $P$. triticina that were tested produced a unique pattern of AFLP alleles confirming the high genetic diversity within populations of the leaf rust fungus described by McDonald and Linde (2002). In contrast, analysis of $P$. triticina isolates from Western Europe using eight RAPD primers revealed only low variability and provided evidence of clonal migration over considerable distances in Western Europe (Park et al., 2000). The low diversity detected in these studies, however, may be also due to the lower sensitivity of RAPD-PCR to fine levels of genetic variation.

Grouping of pathogen isolates based on the region of collection The highly significant differences $(\mathrm{P} \leq 0.01)$ within and between regions of collection showed that there was regional variation in terms of genetic diversity of pathogen isolates. The 'within-region' comparison indicated that isolates collected from central Ethiopia had the lowest GS of the three regions. This might be attributed to the cultivation of both indigenous and commercial durum wheat cultivars as well as bread wheat cultivars in the region. Durum wheat genotypes in the region are reported to be of high genetic diversity (Tessema and Belay, 1991). In effect, isolates with high complementary genetic diversity might co-exist with a wider range of durum wheat genotypes.

South and south-east Ethiopia, on the other hand, is known for its bread wheat cultivation. The Arsi Administrative Region (south-east Ethiopia) was reported to account for about $75 \%$ of Ethiopia's total bread wheat area (Ensermu et al., 1998). As bread wheat is not indigenous to Ethiopia, these cultivars are developed through selection and crossing programmes mainly using genetic materials introduced from abroad. As a result, bread wheat cultivars in Ethiopia have a narrow genetic base (Gebre-Mariam, 1991). According to Badebo (2002), 


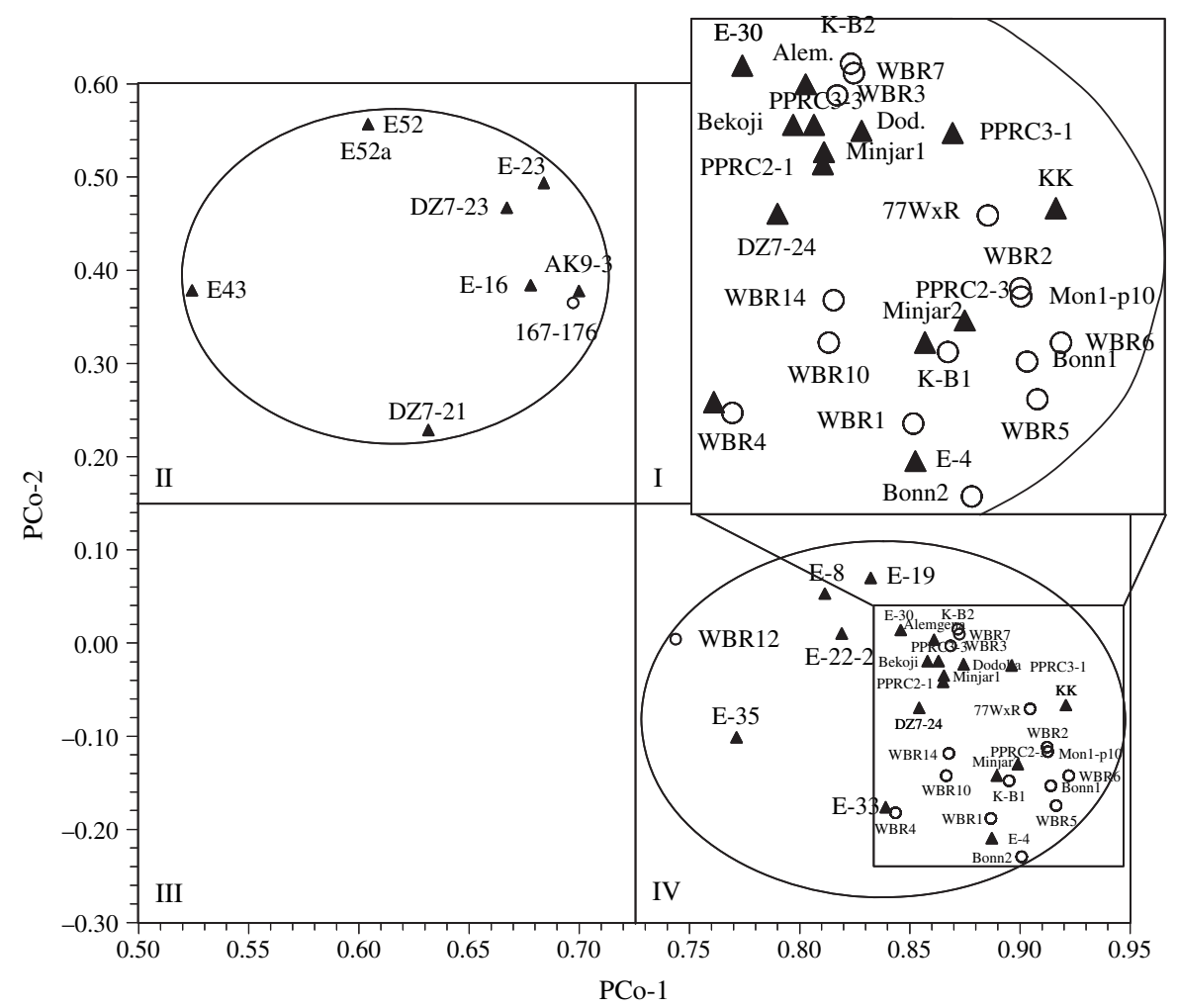

Fig. 2 Two-dimensional principal coordinate analysis (PCoA) plot of 43 Puccinia triticina isolates collected from Ethiopia ( $\mathbf{\Delta})$ and Germany (O) based on Dice's GS values calculated from 219 polymorphic AFLP fragments. Sections II and IV (rectangular sector magnified in insert in section I) presented the less and more genetically similar groups of isolates as shown in clusters I and II, respectively, of the dendrogram in Fig. 1

Table 5

Frequency of selected AFLP alleles in wheat leaf rust isolates from central and south and south-east Ethiopia and Germany

\begin{tabular}{|c|c|c|c|c|c|c|}
\hline \multirow[b]{2}{*}{ Allele } & \multicolumn{2}{|c|}{ Central Ethiopia $(n=14)$} & \multicolumn{2}{|c|}{$\begin{array}{l}\text { South and south-east } \\
\text { Ethiopia }(n=12)\end{array}$} & \multicolumn{2}{|c|}{ Germany $(n=17)$} \\
\hline & No. isol. ${ }^{\mathrm{a}}$ & $\mathrm{AF}$ & No. isol. ${ }^{\mathrm{a}}$ & $\mathrm{AF}$ & No. isol. ${ }^{\mathrm{a}}$ & $\mathrm{AF}$ \\
\hline E-AC/M-CTG-8 & 3 & 0.214 & 0 & 0.000 & 0 & 0.000 \\
\hline E-AC/M-CTC-6 & 3 & 0.214 & 1 & 0.083 & 0 & 0.000 \\
\hline E-AG/M-CAG-6 & 8 & 0.571 & 12 & 1.000 & 17 & 1.000 \\
\hline E-AG/M-CAC-17 & 8 & 0.571 & 11 & 0.917 & 17 & 1.000 \\
\hline E-AG/M-CAG-9 & 7 & 0.500 & 10 & 0.833 & 17 & 1.000 \\
\hline
\end{tabular}

AF, allele frequency.

a Number of isolates in which the particular allele is observed.

the semi-dwarf bread wheat cultivars widely produced in south and south-east Ethiopia lack adequate genetic variation for resistance to rusts because they are of similar genetic background. Such cultivars are mostly released for production with a single gene for rust resistance. Depending on the selection pressure, i.e. the area grown with the cultivar, this specific disease resistance is overcome by the appearance of new virulence genes in the pathogen population which enables the new isolate(s) to attack all cultivars with a similar genetic background for leaf rust resistance. For instance, of the 26 rust resistant bread wheat cultivars released in the period 1970-1993, only three retained their resistance (Assefa, 2001). Eventually, host selection due to narrow genetic make-up reduces genetic diversity in the pathogen population. The same may be true also for the German leaf rust population. Similar to the very similar diversity of P. triticina isolates from Germany and south and south-east Ethiopia, the level of genetic diversity in leaf rust collections in Egypt in 1998-2000 was similar to that of collections from the Southern and Central Plains of the USA in the same period (McVey et al., 2004).

The 'between-regions' comparison showed that the isolates collected from Germany were more genetically similar to the south and south-east Ethiopian isolates. As both regions are used predominantly for the 
production of bread wheat, the leaf rust populations in these regions may have largely adapted to Triticum aestivum. As there is no or little evidence that sexual reproduction plays an important role in the formation of new pathotypes (Kolmer and Liu, 2000), the genetic diversity of $P$. triticina populations observed in our study may not be attributed to recombination.

\section{Clustering and PCoA}

Distinct geographical clustering was observed among isolates of the soil-borne stramenopile Pythium insidiosum (Schurko et al., 2003) and species of the basidiomycete Coprinus (Ko et al., 2001). It was plausible to expect the Ethiopian and German leaf rust populations to cluster based on the region of collection. However, no geographical (based on country of origin) clustering was observed in the present study. The highly significant difference between the two clusters clearly justified the validity of clustering the isolates into two groups. Kolmer and Liu (2000) also found $P$. triticina isolates from Italy and Spain and from Canada and South America to be clustered together based on RAPD marker differences. A positive correlation between the genetic diversity of isolates and the geographical distance has been reported for Gibberella zeae in the USA (Zeller et al., 2004), Sclerospora graminicola in India (Singru et al., 2003) and Alternaria brassicicola in New South Wales (Bock et al., 2002). For isolates of Beauveria bassiana from Kenya (De Muro et al., 2003), Fusarium semitectum on cotton in Egypt (Abd-Elsalam et al., 2003) and Peronospora sparsa in Finland (Lindqvist-Kreuze et al., 2002), however, no correlation between physical distance of origin and genetic diversity could be established.

In cluster I of the dendrogram and section IV of PCoA, the majority of isolates from both countries were clustered together with a minimum average GS value of $0.59 \pm 0.06$. The fact that nearly all isolates from Germany and south and south-east Ethiopia were grouped in this cluster indicated that the isolates from the two regions were more genetically similar.

Cluster II consisted of more genetically diverse isolates than the isolates in cluster I. Seven isolates of cluster II were from Ethiopia and only one from Germany. Of the seven isolates in this cluster, six were collected from central Ethiopia. E-43, the only isolate in this group collected from south and south-east Ethiopia, was collected from the durum wheat cultivar Gerardo. In this cluster was also the German isolate, 167-176. It was collected before 1990 and no information on the region of collection or the type of the host cultivar from which the sample was collected is available. The fact that the majority of isolates in this cluster belong to central Ethiopia might show the genetic variability of central Ethiopian isolates. This high variability might be of supporting evidence for the specificity (Ezzahiri, 2000) of central Ethiopian isolates to durum wheat cultivars

\section{Allele frequency}

The allele sharing of isolates from Germany and south and south-east Ethiopia also indicates that the isolates in both regions have a very similar genetic background. Allele E-AC/M-CTG-8 detected in isolates from central Ethiopia was missing in both regions; allele E-AG/M-CAG-6 was present in all isolates from both regions confirming a high genetic similarity between the isolates of the two regions. These two alleles were not shared in similar manners by the isolates from central Ethiopia demonstrating genetic distinctiveness of isolates from this region. This might be due to co-evolution of the isolates with the durum wheat genotypes grown in the region.

The specific adaptation of leaf rust isolates to durum wheat has been recognized since the 1940s. Isolates of the wheat leaf rust fungus collected from durum wheat cultivars were reported to be distinct from those isolates adapted to bread wheat (Ezzahiri, 2000). HuertaEspino (1992) and Martinez et al. (2005) also found that populations of the pathogen on durum wheat cultivars were quite distinct from populations on bread wheat cultivars. Ezzahiri et al. (1994) reported on a greater diversity of virulence genes in leaf rust isolated from durum wheat than from most bread wheat cultivars. In Morocco, durum wheat is often grown in marginal areas where the alternate host Anchusa italica occurs. In conclusion, the results of the present study revealed that the wheat leaf rust population in central Ethiopia has a distinct genetic background. The genetic differentiation might be related to the predominant cultivation of durum wheat in the region. However, further studies, with larger number of isolates and with supporting virulence data are required to consolidate this conclusion.

\section{Acknowledgements}

The authors thank Dr Kerstin Flath, Federal Biological Research Center for Agriculture and Forestry (BBA), Kleinmachnow, for provision of the leaf rust isolates from Germany. The first author is also indebted to Ms Hedda von Quistorp for her excellent technical assistance on the AFLP analysis.

\section{References}

Abd-Elsalam KA, Schnieder F, Asran-Amal A, Khalil MS, Verreet JA. (2003) Intra-species genomic groups in Fusarium semitectum and their correlation with origin and cultural characteristics. J Plant Dis Prot 110:409-418.

Assefa S. Exploiting alien resistance genes in Aegilops tauschii and their utilization for the development of bread wheat genotypes with multiple resistance to major diseases. $\mathrm{PhD}$ thesis, Goettingen, Georg-August University, 2001.

Badebo A. Breeding bread wheat with multiple disease resistance and high yield for the Ethiopian highlands: broadening the genetic basis of yellow rust and tan spot resistance. PhD thesis, Goettingen, Georg-August University, 2002.

Bock CH, Thrall PH, Brubaker CL, Burdon JJ. (2002) Detection of genetic variation in Alternaria brassicicola using AFLP fingerprinting. Mycol Res 106:428-434.

Brown JKM. (1996) The choice of molecular marker methods for population genetic studies of plant pathogens. New Phytol 133:183-195.

De Muro MA, Mehta S, Moore D. (2003) The use of amplified fragment length polymorphism for molecular analysis of Beauveria 
bassiana isolates from Kenya and other countries, and their correlation with host and geographical origin. FEMS Microbiol Lett 229:249-257.

Dehne H-W, Oerke E-C. Impact of diseases and disease control on crop production. In: Hutson DH, Miyamoto J (eds), Fungicidal Activity: Chemical and Biological Approaches to Plant Protection, Chichester, New York, Wiley and Sons, 1998, pp. 1-21.

Ensermu R, Mwangi W, Verkuijl H, Hassena M, Alemayehu Z. Farmers' Wheat Seed Sources and Seed Management in Chilalo Awraja, Ethiopia. Mexico, D.F., IAR and CIMMYT, 1998.

Ezzahiri B. Leaf rust of durum wheats. In: Royo C, Nachit MM, Di Fonzo N, Araus JL (eds), Durum Wheat Improvement in the Mediterranean Region: New Challenges, Proceedings of the seminar jointly organised by CIHEAM, Centre Udl-IRTA, CIMMYT and ICARDA, Zaragoza, Spain, 12-14 April 2000, Zaragoza, CIHEAMUdl-IRTACIMMYT/ACARDA, 2000, 357-361 (ISBN: 2-85352212-1).

Ezzahiri B, Diouri S, Roelfs AP. (1992) The role of the alternate host, Anchusa italica, in the epidemiology of Puccinia recondita f.sp. tritici on durum wheat in Morocco. In: Zeller FJ, Fischbeck $\mathrm{G}$ (eds), Proceedings of the 8th European and Mediterranean Cereal Rusts and Mildews Conference, Weihenstephen, Germany, Vorträge für Pflanzenzüchtung 24, 1992, pp. 69-70.

Ezzahiri B, Diouri S, Roelfs AP. (1994) Pathogenicity of Puccinia recondita f.sp. tritici in Morocco during 1985, 1988, 1990, and 1992. Plant Dis 78:407-410.

Gebre-Mariam H. Wheat production and research in Ethiopia. In: Gebre-Mariam H, Tanner DG, Hulluka M (eds), Wheat Research in Ethiopia: A Historical Perspective, Addis Ababa, Ethiopia, IAR/CIMMYT, 1991, pp. 1-16.

Geleta B, Tanner DG. Status of cereal production and pathology research in Ethiopia. In: Danial DL (ed.), Breeding for Disease Resistance with Emphasis on Durability. Proc Regional Wheat Workshop for Eastern Kenya, Central and Southern Africa, 2-6 October 1994, Njoro, Kenya, 1995, pp. 42-50.

Huerta-Espino J. Analysis of wheat leaf and stem rust virulence on a worldwide basis. PhD thesis, St Paul, MN, University of Minnesota, 1992.

Kauserud H, Stensrud O, Decock C, Shalchian-Tabrizi K, Schumacher T. (2006) Multiple gene genealogies and AFLPs suggest cryptic speciation and long-distance dispersal in the basidiomycete Serpula himantioides (Boletales). Mol Ecol 15:421-431.

Keiper FJ, Hayden MJ, Park RF, Wellings CR. (2003) Molecular genetic variability of Australian isolates of five cereal rust pathogens. Mycol Res 107:545-556.

Khan MA, Trevathan LE, Robbins JT. (1997) Quantitative relationship between leaf rust and wheat yield in Mississippi. Plant Dis 81:769-772.

Ko KS, Lim YW, Kim YH, Jung HS. (2001) Phylogeographic divergences of nuclear ITS sequences in Coprinus species sensu lato. Mycol Res 105:1519-1526.

Kolmer JA. (1993) Selection in a heterogeneous population of Puccinia recondita f.sp. tritici. Phytopathology 83:909-914.

Kolmer JA, Liu JQ. (2000) Virulence and molecular polymorphism in international collections of the wheat leaf rust fungus Puccinia triticina. Phytopathology 90:427-436.

Kolmer JA, Liu JQ, Sies M. (1995) Virulence and molecular polymorphism in Puccinia recondita f.sp. tritici in Canada. Phytopathology 85:276-285.

Leisova L, Kucera L, Minarikova V, Ovesna J. (2005a) AFLP-based PCR markers that differentiate spot and net forms of Pyrenophora teres. Plant Pathol 54:66-73.

Leisova L, Minarikova V, Kucera L, Ovesna J. (2005b) Genetic diversity of Pyrenophora teres isolates as detected by AFLP analysis. J Phytopathology 153:569-578.

Leung H, Nelson RJ, Leach JE. (1993) Population structure of plant pathogenic fungi and bacteria. Adv Plant Pathol 10:157-205.

Lindqvist-Kreuze H, Koponen H, Valkonen JPT. (2002) Variability of Peronospora sparsa (syn. P. rubi) in Finland as measured by amplified fragment length polymorphism. Eur $J$ Plant Pathol 108:327-335.
Majer D, Mihten R, Lewis BG, Vos JP, Oliver RP. (1996) The use of AFLP fingerprinting for the detection of genetic variation in fungi. Mycol Res 100:1107-1111.

Martinez F, Sillero JC, Rubiales D. (2005) Pathogenic specialization of Puccinia triticina in Andalusia from 1998 to 2000. J Phytopathol 153:344-349.

Martinez SP, Snowdon R, Pons-Kuhnemann J. (2004) Variability of Cuban and international populations of Alternaria solani from different hosts and localities: AFLP genetic analysis. Eur J Plant Pathol 110:399-409.

McDonald BA, McDermott JM. (1993) Population genetics of plant pathogenic fungi. Bioscience 43:311-319.

McDonald BA, Linde C. (2002) Pathogen population genetics, evolutionary potential, and durable resistance. Annu Rev Phytopathol 40:349-379.

McVey DV, Nazim M, Leonard KJ, Long DL. (2004) Patterns of virulence diversity in Puccinia triticina on wheat in Egypt and the United States in 1998-2000. Plant Dis 88:271-279.

Menzies JG, Bakkeren G, Matheson F, Procunier JD, Woods S. (2003) Use of inter-simple sequence repeats and amplified fragment length polymorphisms to analyze genetic relationships among small grain-infecting species of Ustilago. Phytopathology 93: $167-175$.

Mueller UG, Wolfenbarger LL. (1999) AFLP genotyping and fingerprinting. Tree 14:389-394.

Nei M, Li WH. (1979) Mathematical model for studying genetic variation in terms of restriction endonucleases. Proc Natl Acad Sci USA 76:5269-5273.

Park RF, Felsenstein FG. (1998) Physiological specialization and pathotype distribution of Puccinia recondita in Western Europe, 1995. Plant Pathol 47:157-164.

Park RF, Goyeau H, Felsenstein FG, Bartos P, Zeller FJ. (2001) Regional phenotypic diversity of Puccinia triticina and wheat host resistance in Western Europe. Euphytica 122:113-127.

Park RF, Jahoor A, Felsenstein FG. (2000) Population structure of Puccinia recondita in western Europe during 1995, as assessed by variability in pathogenicity and molecular markers. J Phytopathol 148:169-179.

Pillen K, Binder A, Kreuzkam B, Ramsay L, Waugh R, Foerster J, Léon J. (2000) Mapping new EMBL-derived barley microsatellites and their use in differentiating German barley cultivars. Theor Appl Genet 101:652-660.

Radisek S, Jakse J, Simoncic A, Javornik B. Hop wilt in Slovenia: current situation and diagnostic research. In: Seigner E (ed.), Proceedings of the Scientific Commission, International Hop Growers' Convention (IHGC), 24-27 June 2003, Slovenia, Dobrna-Zalec, 2003, pp. 17-21

Rau D, Brown AH, Brubaker CL, Attene G, Balmas V, Saba E, Papa R. (2002) Population genetic structure of Pyrenophora teres Drechs. the causal agent of net blotch in Sardinian landraces of barley (Hordeum vulgare L.). Theor Appl Genet 106:947-959.

Rau D, Maier FJ, Papa R, Brown AHD, Balmas V, Saba E, Schaefer W, Attene G. (2005) Isolation and characterization of the mating-type locus of the barley pathogen Pyrenophora teres and frequencies of mating-type idiomorphs within and among fungal populations collected from barley landraces. Genome 48:855-869.

Schmidt H, Niessen L, Vogel RF. (2004) AFLP analysis of Fusarium species in the section Sporotrichiella - evidence for Fusarium langsethiae as a new species. Int J Food Microbiol 95:297-304.

Schnieder F, Koch G, Jung C, Verreet JA. (2001) Genotypic diversity of the wheat leaf blotch pathogen Mycosphaerella graminicola (anamorph) Septoria tritici in Germany. Eur $J$ Plant Pathol 107:285-290.

Schurko A, Mendoza L, de Cock AWAM, Klassen GR. (2003) Evidence for geographic clusters: molecular genetic differences among strains of Pythium insidiosum from Asia, Australia and the Americas are explored. Mycologia 95:200-208.

Singru R, Sivaramakrishnan S, Thakur RP, Gupta VS, Ranjekar PK. (2003) Detection of genetic variability in pearl millet downy mildew (Sclerospora graminicola) by AFLP. Biochem Genet 41:361-374. 
Tessema T, Belay G. Aspects of Ethiopian tetraploid wheats with emphasis on durum wheat genetics and breeding. In: Gebre-Mariam H, Tanner DG, Hulluka M (eds), Wheat Research in Ethiopia: A Historical Perspective, Addis Ababa, Ethiopia, IAR/CIMMYT, 1991, pp. 47-71.

Viennot-Bourgin G. (1941) Diagnose latine de Puccinia tritici-duri. Ann. Ecole Nationale Agric. Grignon Ser. 3 2:146.

Von Kröcher C, Bartels G, Fehrmann H. (1992) Untersuchungen zum Rassenspektrum bei Weizenbraunrost (Puccinia recondita
Rob. ex Desm. f.sp. tritici Eriks. \& Henn.). Z PflKrankh PflSchutz 99:137-144.

Vos P, Hogers R, Bleeker M et al. (1995) AFLP: a new technique for DNA fingerprinting. Nucleic Acids Res 23:4407-4414.

Zeller KA, Bowden RL, Leslie JF. (2004) Population differentiation and recombination in wheat scab populations of Gibberella zeae from the United States. Mol Ecol 13:563-571. 